A New Angle on Health

(Nature's Provision for the Health and Happiness of Mankind). By Surg.-Capt. D. H. C. Given. Pp. $\mathrm{xvii}+160+5$ plates. (London: John Bale, Sons and Danielsson, Ltd., 1935.) 7s. 6d. net:

THE author of this book was for more than eight years stationed at Singapore, and this he claims has given him a unique opportunity to contrast the health of a primitive Asiatic community of diverse races with that of naval personnel and white civilians. He finds that the physical standard of the Asiatic labourer is $A 1$, as compared with the $C 3$ standard of civilisation, that his teeth are on a par with his physical standard, and that he does not suffer from the diseases common among Western races.

It is to be noted that in the Asiatic labourer of Singapore, the author is dealing with a very selected and restricted group, which cannot be compared with our own population as a whole. Similarly, when it is stated that in contrast to the European, the epidemic influenza in the Asiatic in 1931 was mild and free from complications, it should be recalled that India and South Africa suffered some years ago from a devastating epidemic of influenza, and this disease in native races is not necessarily a mild one; in fact, one epidemic may differ entirely in severity and in incidence from another one.

Basing his arguments on what in many instances we believe are faulty premises, the author attributes the ills from which we suffer to the effects of urbanisation, overcrowding, extremes of poverty and riches, the decline of agriculture, and under- and improper feeding-much of which is doubtless true-and condemns our Western civilisation as being founded on selfish greed, industrialism and parasitism. $\mathrm{He}$ concludes that so long as selfishness continues to dominate the lives of men, so long will the human race fail to realise the happiness for which it strives, and that the precepts of Christianity form the only basis of a healthy and happy life. R. T. Hewlert.

\section{Technics and Civilization}

By Lewis Mumford. Pp. xi $+495+16$ plates. (London George Routledge and Sons, Ltd., 1934.) 18s. net.

THIs book provides an interesting and thoughtprovoking contribution to the history of the machine and its sociological effects on humanity. Mr. Mumford divides the machine age into three great periods : (1) the 'eotechnic' based on animal, water and wind power; (2) the 'paleotechnic' which came in with Watt's steam engine and had its basis in coal and iron, and (3) the 'neotechnic' which is now dawning and promises industrial decentralisation, cleanness, leisure and abundance, its basis being the longdistance transmission of electric power.

Discussing the assimilation of the machine, $\mathrm{Mr}$. Mumford points out that as machinery was developed, attention came to be centred more and more on the product, people valuing the machine for what it produced. The machine thus appeared purely as an external instrument for the conquest of the environment to the neglect of the actual forms of the products, the actual collaboration and intelligence manifested in creating them and the educational possibilities of this impersonal co-operation itself. The objects rather than the spirit that produced them were assimilated, and so far from respecting that spirit, the aim was to make the objects themselves seem to be something other than the product of the machine. The industrialists and engineers themselves did not believe in the qualitative and cultural aspects of the machine. The possibility that technics had become a creative force which was rapidly ordering a new kind of environment and producing a third estate midway between Nature and the humane arts, was far from the minds of those who actively promoted the mechanisation of production.

\section{The Recollections of a Geographer}

By E. A. Reeves. Pp. $224+8$ plates. (London: Seeley, Service and Co., Ltd., n.d.) $8 s .6 d$. net.

AFTER fifty-five years service in the Royal Geographical Society as map curator and instructor in surveying, Mr. Reeves retired in 1933. Many hundred travellers and explorers have owed to him all they knew of survey work, so that his influence has reached to every corner of the globe. Here are glimpses of men like Stanley, Bates, Burton, Nansen and many others who brought their observations and discoveries to the Society.

Mr. Reeves has anecdotes about many and a kindly word for all. He has allowed no adverse criticism to appear in his pages; but he has clearly omitted many of his experiences, for the book is not long as a record of half a century of noteworthy people. A hurried sketch of the progress of exploration and survey in that period is included as well as some account of Mr. Reeves's own work on magnetism and in the improvement of surveying instruments. Finally, there is an unconvincing chapter on the author's psychic experiences.

It is a kindly and ingenuous book that to many will recall a teacher of great ability and untiring patience, and to others will appeal as a sketch of fifty years of discovery as seen from the Royal Geographical Society, by the one man above all others who has directed exploration.

\section{Diesel Engine Design}

By Harold F. Shepherd. Pp. vii +277 . (New York : John Wiley and Sons, Inc.; London : Chapman and Hall, Ltd., 1935.) 17s. $6 d$. net.

The Diesel engine has now been constructed successfully in so many different types that any book on its design which is not restricted to one particular line of development must almost necessarily become too discursive to be of practical value to the designer. It is in this respect that H. F. Shepherd's "Diesel Engine Design" fails to meet the real need for a book or series of books on this subject. The historical and descriptive treatment and the discussions on numerous points which arise in design are all to the good; but the author does not really grapple with the actual problem of design until the last chapter or two. It is an introduction to, rather than a manual on, design.

J.A. C. 